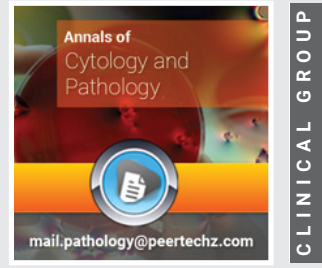

\title{
Micronucleus scoring: An available approach in the evaluation of genomic damage in exfoliative cervicovaginal
}

\section{cells}

\section{Zehra SAFI OZ*}

Department of Medical Biology, Zonguldak Bülent Ecevit University School of Medicine, Zonguldak, Turkey

\section{Abstract \\ Micronucleus is small chromatin extranuclear bodies when chromosomes or chromosomal fragments are not included in the nucleus during cell division. Micronucleus formation usually serves as a sensible indicator of genotoxic damage and also a morphological marker of chromosomal instability. Genomic damage is crucial for the development of degenerative diseases, including cancer. MN assay is a reliable and applicable method on many cell types such as erythrocytes, leucocytes and epithelial cells and it represents an important tool for evaluating DNA damage and defects in mitosis. The purpose of this article is to provide an overview of the current status of the micronuclei scoring in exfoliated epithelial cells and to highlight the importance of this procedure.}

\section{Abbreviations}

DAPI: 4',6-Diamidino-2-Phenylindole, Dihydrochloride; LBC: Liquid Based Cytology; MN: Micronucleus; PAP: Papanicolaou test

\section{Review of the literature}

Micronucleus (the plural is micronuclei) was first identified by Howell and Jolly in red cell precursors and was also referred as Howell-Jolly bodies [1]. At that time, these bodies were described as nuclear remnants (clusters of DNA) in the circulating erythrocytes. After a while, MN was described in lymphocytes, exfoliated buccal and cervicovaginal epithelial cells [1-3]. Extranuclear cytoplasmic bodies of the damaged chromosome fragments and/or whole chromosomes form $M N$. It is not incorporated into the nucleus after cell division [2]. $\mathrm{MN}$ is also a sensible indicator of the genetic damage and linked to various chromosome aberrations such as defective mitotic figures, chromosome fragmentations, mitotic cell death and catastrophe, giant nuclear, and especially genome
Received: 15 June, 2020

Accepted: 20 June, 2020

Published: 22 June, 2020

*Corresponding author: Zehra SAFI OZ, Department of Medical Biology, Zonguldak Bülent Ecevit University School of Medicine, Zonguldak, Turkey, Tel: +90 (372) 2613228; Fax: +90 (372) 2610264;

E-mail: safizehra@yahoo.com

Keywords: Micronucleus; Micronucleus assay; Genomic instability; DNA damage; Exfoliative cytology

https://www.peertechz.com

Check for updates chaos [4-7]. Genomic damage may occur due to medical factors such as radiation and chemicals and also due to the deficiency of some micronutrients. Lifestyle factors such as alcohol, smoking, stress and genetic factors are also important for the development of genomic damage [6-13]. MN assay can be applied to exfoliative epithelial cells to screen population groups at risk for cancer [14-16]. It can also be used as a biomarker to examine the effects of infection agents [17-19].

\section{History of micronuclei}

Micronucleus test was suggested for the first time by Boller, Schmidt and Heddle in the early 1970s. A few years later Countryman and Heddle could be used for the micronucleus approach in the peripheral blood lymphocytes [3]. In 1982, MN technique was first described by Stich and colleaques in exfoliative cells of the buccal mucosa for human biomonitoring studies [11]. Exfoliated cells can be used in several types of cell obtained from buccal and cervical mucosa, bronchi, urinary bladder etc. MN assay seems to represent a useful 'internal dosimeter' for estimating exposure to genotoxic agents $[8,14,20]$. 


\section{Micronuclei formation}

The basal layer of squamous epithelium contains the basal cells which are cuboidal-shaped stem cells. During nuclear division, genetic damage may express as $M N$ in these cells [2,3]. According to the knowledge accumulated in literature, some genetic and epigenetic mechanisms effects the formation of $\mathrm{MN}$ [2]. There are concisely three mechanisms that may contribute to this process. These are chromosomal breakage, dysfunction of the mitotic apparatus and broken anaphase bridges $[16,19]$. Agents that stimulate aneuploidy cause centromere division errors and mitotic spindle failure. The classtogens also contribute to $\mathrm{MN}$ formation lead to chromosome breaks [2].

\section{Criteria for the evaluation of micronuclei in exfoliated cells}

One of the most important criteria for the evaluation of $\mathrm{MN}$ in exfoliated epithelial cells is the counting of nuclei and cells with intact boundaries $[18,19]$. Heddle (1973) initially described the well-established criteria for identifying $\mathrm{MN}$ but he did not provide the cell inclusion criteria. Stich and Rosin (1983) established the criteria for inclusion of cells for MN frequency, and later Tolbert, et al. developed the criteria $[12,15]$. Tolbert, et al. suggested that the criteria for identifying micronucleus should be as follows:

- The diameter of the MN should be less than one-third of the main nucleus, but large enough to discern shape and color

- MN should have similar texture and staining as the main nucleus

- MN should have the same focal plane as nucleus

- MN should have rounded smooth perimeter suggestive of a membrane

- MN should be separated from or marginally overlap with main nucleus as long as there is a clear identification of the nuclear boundary.

In general, the most commonly used method is the zigzag method for screening of the slides. Tolbert et al. also recommended the scoring of at least 1000 cells. If less than 5 micronucleated cells were found after counting 1000 cells, he suggested to count $2000-3000$ cells $[6,21]$.

\section{Exfoliative cytology and Papanicolaou test (Pap test)}

The cervicovaginal epithelium is composed of several distinct layers or strata. This rapid turnover of epithelial tissue brings the cells to the surface, where they exfoliate $[3,22]$. Exfoliation of cells is one of the main mechanisms of cell loss participating in the homeostatic control of cell population size. Exfoliated epithelial cells have some advantages such as a good definition of nuclear detail, cytoplasmic transparency [23]. General appearances of cervicovaginal samples and epithelial cells with different infection agent were seen in Figure 1.

In Figure 2, micronucleated exfoliated epithelial cells with different infection agents and cervical intraepithelial neoplasia were shown.

Pap test is an easily performed, quick, noninvasive, inexpensive and safe methods to screen for preinvasive, invasive cervical cancer and the effects of gynecological infection agents [24]. Cervical cancer is the fourth most common cancer in female. Pap test can help prevent cervical cancer [25-27].
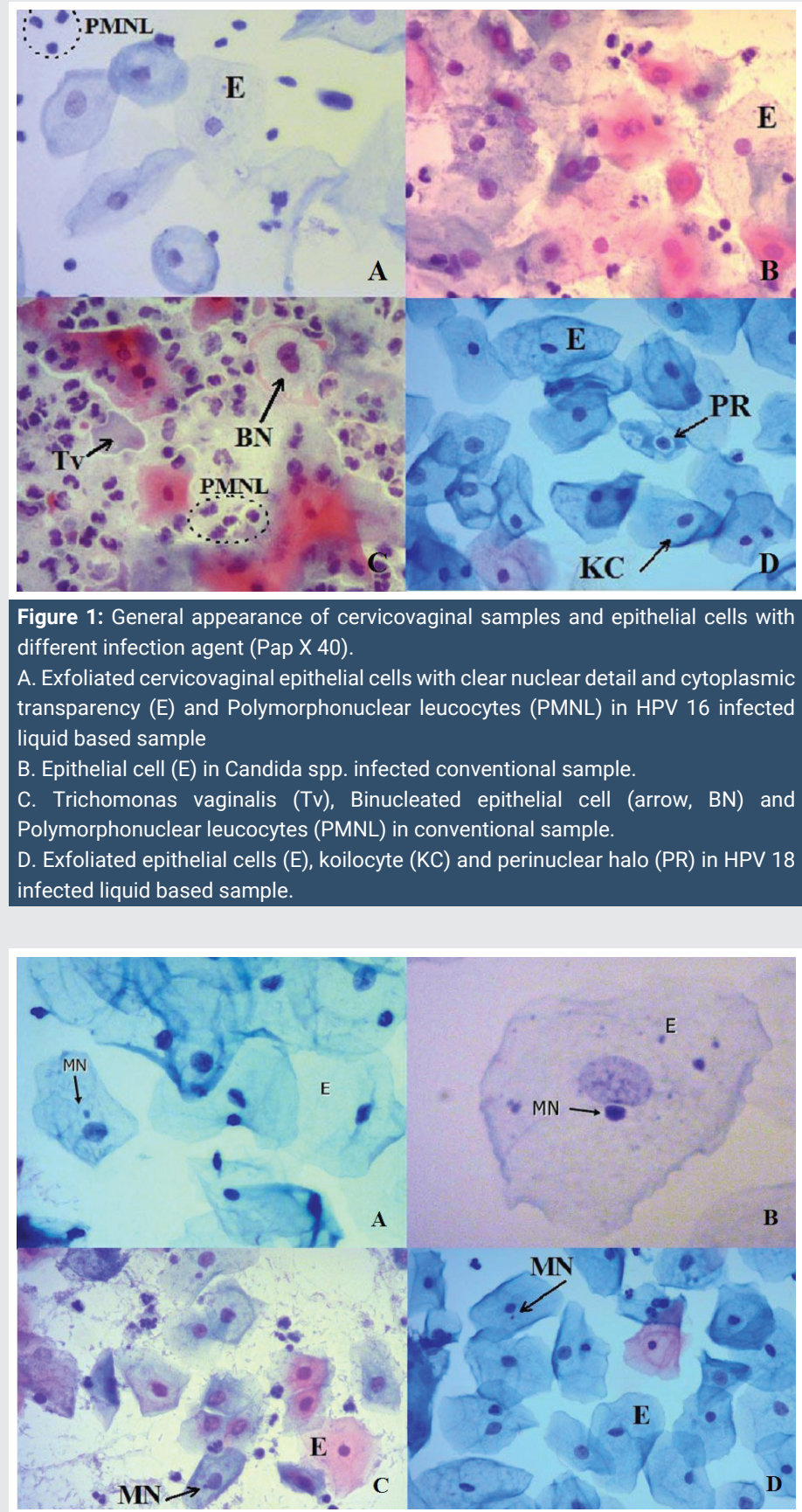

Figure 2: Micronucleated exfoliated cervicovaginal epithelial cells with different infection agents and cervical intraepithelial neoplasia (Pap X 40)

A. Micronucleus (arrow, MN) and epithelial cells (E) in cervical intraepithelial neoplasia

B. Cervicovaginal epithelial cell (E) and micronucleus (arrow, MN) in cervical intraepithelial neoplasia (Pap X 100).

C. Micronucleus (arrow, MN) and exfoliated epithelial cells (E)) in Candida spp. infected conventional cervicovaginal sample.

Micronucleus (arrow, MN) and exfoliated epithelial cells (E) in HPV 18 infected liquid based cervical sample. 
This test can be performed via the conventional method and liquid based cytology. In the conventional method, exfoliated epithelial cells were layered on a glass slide and immediately fixed with appropriate fixative. In LBC, cells are stored in a vial containing a special liquid. LBC had better performance than conventional Pap test $[26,28]$. Light microscopic analysis of $\mathrm{MN}$ in cervical smears increases the sensitivity and specificity of cytology in the evaluation of cellular pictures due to genomic instability [19].

\section{Micronucleus scoring and the interaction between MN and gynecological infections}

MN scoring can be performed immediately by using microscopy and it can be screened in various diseases, infection agents, cervical intraepithelial lesions and carcinoma [17$19,29]$. MN scoring on the epithelial cells of cervix can be used as supplemental in cervical cancer screening. MN requency appears to increase in carcinogen-exposed tissues long before any clinical symptoms are evident [27].

MN assay is a simple, reliable, convenient, cheap and applicable method that can be performed on many cell types and is a noninvasive technique for the evaluation of genetic damage. A variety of different stains can be used for the analysis of micronuclei. Among the most DNA-specific stains, Feulgen is the one which is being most widely used. Acridine orange, propidium iodide 4,6-diamidino-2-phenylindole (DAPI) are also being used for the same purpose. Nonspecific stains (MayGrunwald's Giemsa, Giemsa, and less frequently Orcein) were used in MN scoring about $30 \%$ of the studies on epithelial cells [30]. Palaskar and Jindal have shown that Pap is a better stain for counting MN due to the fact that MN was easily seen in the clear cytoplasm when compared to other stains like Giemsa stain [31]. Ayyad, et al. indicated that Pap test was the preferred method for detecting $\mathrm{MN}$ in the oral epithelial cells after comparing it with May-Grünwald-Giemsa stain [32].

Many studies were published related to the MN assay in exfoliated cervicovaginal epithelial cells with preneoplastic lesions and cancer. The large majority of these studies demonstrated a significant increase in $\mathrm{MN}$ frequency in these patients $[16,33]$. Safi Oz, et al. demonstrated that the frequencies of micronucleated cells were significantly higher in genital Candidiasis and Trichomoniasis [18,19]. Cortés Gutiérrez, et al. demonstrated that MN frequencies were higher in HPV infected Mexican females [17]. Rosin and Anwar stated that MN frequencies were higher in the S. haematobium infected group [34]. In some studies, the limitations of the micronuclei scoring has been reported [3]. A few studies reported at possibility of false-positive results as the bacteria or bacterial colonies, nuclear debris, small stain deposits and keratohyalin granules may resemble to $\mathrm{MN}[3,29,30]$. Safi, et al. indicated that bacteria and bacterial colonies can be differentiated from MN by their characteristic shape, color, staining intensity and smaller size, which is also apparent in the background. Also stain deposits are polymorphic granules in the smear, generally over the cells. Pap staining ensures that the nucleus and cytoplasm of the epithelial cells are clearly stained, ensuring visible and identifiable $\mathrm{MN}$ [30]. MN monitoring could be incorporated into routine screening procedures as an additional criterion for the early detection of cytogenetic damage as used in evaluation of cancer and infectious agents [35].

\section{Conclusion}

This review article summarizes the literature about the current status of the micronuclei scoring and the importance of this procedure in exfoliated cervicovaginal epithelial cells in human beings as an approach for genomic damage. DNA damage can produce a wide variety of effects on human health. Exfoliated epithelial cells have been used in cytology to detect chromosome fractures, morphology disorder, premalignant and malignant changes and infection agents and also for evaluating MN. Because MN assay is a fast, safe and a reliable technique to assess genomic instability and also does not require too much expensive equipment, this test could be incorporated into routine Pap test an additional criterion for the early detection of genomic instability. Consequently, the combination of MN assay and Pap test will increase the sensitivity and specificity of the Pap test by providing information about genomic instability as well as evaluation of cytological parameters.

\section{Acknowledgements}

We would like to sincerely thank Ayşe Ceylan Hamamcioglu for her assistance with preparation of this article.

\section{References}

1. Sears DA, Udden MM (2012) Howell-Jolly Bodies: A Brief Historical Review 343: 407-409. Link: https://bit.ly/3dorfhi

2. Luzhna L, Kathiria P, Kovalchuk O (2013) Micronuclei in genotoxicity assessment: from genetics to epigenetics and beyond. Frontiers in Genetics 4: 131. Link: https://bit.ly/2zPAA42

3. Shashikala R, Indira AP, Manjunath GS, Rao KA, Akshatha BK (2015) Role of micronucleus in oral exfoliative cytology. J Pharm Bioallied Sci 7: S409-S413. Link: https://bit.ly/3147KZ6

4. Majer BJ, Laky B, Knasm“uller S, Kassie SF (2001) Use of the micronucleus assay with exfoliated epithelial cells as a biomarker for monitoring individuals at elevated risk of genetic damage and in chemoprevention trials. Mutat Res 489: 147-172 Link: https://bit.ly/3hTa0se

5. Heng HHQ, Liu G, Stevens JB, Abdallah BY, Horne SD, et al. (2013) Karyotype Heterogeneity and Unclassified Chromosomal Abnormalities. Cytogenet Genome Res 139:144-157. Link: https://bit.ly/2Ymk5WI

6. Sabharwal R, Verma P, Syed MA, Sharma T, Subudhi SK, et al. (2015) Emergence of micronuclei as a genomic biomarker. Indian $\mathrm{J}$ Med Paediatr Oncol 36: 212-218 Link: https://bit.ly/3di4GuF

7. Ye CJ, Sharpe Z, Alemara S, Mackenzie S, Liu G, et al. (2019) Micronuclei and Genome Chaos: Changing the System Inheritance. Genes 10: 366. Link: https://bit.ly/2YjfOTY

8. Demirel S, Zamani AG (2002) Mikronükleus tekniği ve kullanım alanları. Gene Tıp Derg 12: 123-127. Link: https://bit.ly/3doC6lj

9. Jen MH, Hwang JJ, Yang JY, Nabyvanets YB, Hsieh WA, et al. (2002) Micronuclei and nuclear anomalies in urinary exfoliated cells of subjects in radionuclide-contaminated regions. Mutat Res 26: 39-46. Link: https://bit.ly/3dm15fo

10. Carlin V, Artioli AJ, Matsumoto MA, Filho HN, Borgo $E$, et al. (2010) Biomonitoring of DNA damage and cytotoxicity in individuals exposed to 
cone beam computed tomography. Dentomaxillofac Radiol 39: 295-299. Link: https://bit.ly/2NjzOzq

11. Kashyap B, Reddy PS (2012) Micronuclei assay of exfoliated oral buccal cells: Means to assess the nuclear abnormalities in different diseases. J Can Res Ther 8: 184-191. Link: https://bit.ly/2V3iD90

12. Arora P, Devi P, Wazir SS (2014) Evaluation of genotoxicity in patients subjected to panoramic radiography by micronucleus assay on epithelial cells of the oral mucosa. J Dent (Tehran) 11: 47-55. Link: https://bit.ly/3dkulTK

13. Arul P, Smitha S, Masilamani S, Akshatha C (2018) Micronucleus Assay in Exfoliated Buccal Epithelial Cells Using Liquid Based Cytology Preparations in Building Construction Workers. Iran J Pathol 13: 30-37. Link: https://bit.ly/3dqDiL8

14. Stich HF, Stich W, Parida BB (1982) Elevated frequency of micronucleated cells in the buccal mucosa of individuals at high risk for oral cancer: Betel quid chewers. Cancer Lett 17: 125-134. Link: https://bit.ly/31377Pt

15. Stich HF, Rosin MP (1984) Micronuclei in exfoliated human cells as a tool for studies in cancer risk and intervention. Cancer Lett 22: 241-253 Link: https://bit.ly/2Bo1u3v

16. Samanta S, Dey P, Gupta N, Mouleeswaran KS, Nijhawan R (2011) Micronucleus in Atypical Squamous Cell of Undetermined Significance. Diagnostic Cytopathology 39: 242-244. Link: https://bit.ly/37MmSf0

17. Cortés-Gutiérrez E, Dávila-Rodríguez M, Vargas-Villarreal J, Hernández-Garza F, Cerda-Flores RM (2010) Association between human papilloma virus-type infections with micronuclei frequencies. Prague Med Rep 111: 35-41. Link: https://bit.ly/2NfJVp7

18. Safı Oz Z, Doğan Gun B, Ozdamar So (2015) Evaluation of Micronuclei Nuclear Anomalies and the Nuclear/Cytoplasmic Ratio of Exfoliated Cervica Epithelial Cells in Genital Candidiasis Acta Cytologica 59: 180-186. Link: https://bit.ly/37NJs6S

19. Safı Oz Z, Doğan Gun B, Gun MO, Ozdamar SO (2015) Cytomorphometric and Morphological Analysis in Women with Trichomonas vaginalis Infection: Micronucleus Frequency in Exfoliated Cervical Epithelial Cells. Acta Cytologica 59: 258-264. Link: https://bit.ly/2YW1UGj

20. Bhat A, Vijaya C, Padmasri R (2016) Apoptosis and Micronucleus in Cervical Pap Smears: Promising Assays to Increase the Diagnostic Value of The Test. Annals of Pathology Laboratory Medicine 3: 320-328. Link: https://bit.ly/2YnmDDY

21. Tolbert $P$, Shy CM, Allen JW (1992) Micronucleus and other nuclear anomalies in buccal smears: methods development. Mutat Res 271: 69-77. Link: https://bit.ly/3elKb1y

22. Anderson DJ, Marathe J, Pudney J (2014) The structure of the human vaginal stratum corneum and its role in immune defense. Am J Reprod Immunol 71: 618-623. Link: https://bit.ly/2YIUo8D

23. Loktionov A (2011) Exfoliation of Cells. In: Schwab M. (eds) Encyclopedia of Cancer. Springer, Berlin, Heidelberg. Link: https://bit.ly/2V5xdgG

24. Ginsberg CK (1991) Exfoliative Cytologic Screening. The Papanicolaou Test. J Obstet Gynecol Neonatal Nurs 20: 39-46. Link: https://bit.ly/3fRjrXj

25. Safaeian M, Solomon D, Castle PE (2007) Cervical cancer prevention--cervica screening: science in evolution. Obstetrics gynecology clinics of North America 34: 739-760. Link: https://bit.ly/3hR9mvh

26. Giachnaki M, Athanasiadi E, Pouliakis A, Spathis A, Kottaridi C (2016) Comparative Analysis of Conventional and Thin Prep Papanicolaou Test. Technical and Economic Aspects Annals of Cytology and Pathology 1: 018024. Link: https://bit.ly/3dnC6YM
27. Ismail MS, Hsu S, AlKhalifa MA, Fuad Ali M , Codabux MF, et al. (2020) Evaluation of Different Guidelines for Cervical Cancer Screening and Management of Abnormal Cervical Cytology. Annals of Cytology Pathology 5 : 1-12. Link: https://bit.ly/3hLqQci

28. Gupta R, Yadav R, Sharda A, Kumar D, Sandeep R, et al. (2019) Comparative evaluation of conventional cytology and a low-cost liquid-based cytology technique, EziPREP ${ }^{\text {TM }}$, for cervicovaginal smear reporting: A split sample study. Cyto Journal 16: 22. Link: https://bit.ly/3fLVlgt

29. Gayathri B, Kalyani R, Hemalatha A, Vasavi B (2012) Significance of micronucleus in cervical intraepithelial lesions and carcinoma. Journal of cytology 29: 236-240. https://bit.ly/2V5pjEe

30. Safi Oz Z, Dogan Gun B, Ozdamar SO (2015) Why an Experienced Eye May Not Detect Micronucleated Cells Using Papanicolaou's Stain. Acta Cytol 59 431-433. Link: https://bit.ly/3eq3LK7

31. Palaskar S, Jindal C (2010) Evaluation of micronuclei using papanicolaou and May grunwald giemsa stain in individuals with different tobacco habits - A comparative study. J Clin Diagn Res 4: 3607-3613. Link: https://bit.ly/315Di00

32. Ayyad SBA, Israel E, El-Setouhy M, Radwan G (2006) Evaluation of Papanicolaou Stain for Studying Micronuclei in Buccal Cells Under Field Conditions. Acta cytol 50: 398-402. Link: https://bit.ly/37NKEXU

33. Shi YH, Wang BW, Tuokan T, Li QZ, Zhang YJ (2015) Association between micronucleus frequency and cervical intraepithelial neoplasia grade in Thinprep cytological test and its significance. Int J Clin Exp Pathol 8: 84268432. Link: https://bit.ly/2NIfvBP

34. Rosin MP, Anwar W (1992) Chromosomal damage in urothelial cells from Egyptians with chronic Schistosoma haematobium infections. Int $\mathrm{J}$ Cancer 50: 539-543. Link: https://bit.ly/3fl5xGP

35. Bueno CT, Dornelles da Silva CM, Barcellos RB, da Silva J, Dos Santos CR, et al. (2014) Association between cervical lesion grade and micronucleus frequency in the Papanicolaou test. Genetics and molecular biology 37: 496499. Link: https://bit.ly/313Fx4p

Discover a bigger Impact and Visibility of your article publication with Peertechz Publications

\section{Highlights}

* Signatory publisher of ORCID

* Signatory Publisher of DORA (San Francisco Declaration on Research Assessment)

* Articles archived in worlds' renowned service providers such as Portico, CNKI, AGRIS, TDNet, Base (Bielefeld University Library), CrossRef, Scilit, J-Gate etc.

* Journals indexed in ICMJE, SHERPA/ROMEO, Google Scholar etc.

- OAI-PMH (Open Archives Initiative Protocol for Metadata Harvesting)

* Dedicated Editorial Board for every journa

* Accurate and rapid peer-review process

- Increased citations of published articles through promotions

* Reduced timeline for article publication

Submit your articles and experience a new surge in publication services (https://www.peertechz.com/submission).

Peertechz journals wishes everlasting success in your every endeavours.

Copyright: @ 2020 Zehra SAFI OZ. This is an open-access article distributed under the terms of the Creative Commons Attribution License, which permits unrestricted use, distribution, and reproduction in any medium, provided the original author and source are credited.

Citation: Zehra SAFI OZ (2020) Micronucleus scoring: An available approach in the evaluation of genomic damage in exfoliative cervicovaginal cells. Ann Cyto Pathol 5(1): 064-067. DOI: https://dx.doi.org/10.17352/acp.000018 